\title{
Pengaruh Tingkat Pendidikan, Usia Perkawinan Pertama dan Kematian Bayi terhadap Fertilitas di Kabupaten Aceh Timur
}

\author{
Nurlaila Hanum \\ Fakultas Ekonomi Universita Samudra \\ e-mail:nurlailahanum@unsam.ac.id \\ Puti Andiny \\ Fakultas Ekonomi Universita Samudra \\ e-mail:putiandiny@unsam.ac.id
}

\begin{abstract}
Abstrak
Penelitian ini bertujuan untuk mengetahui pengaruh pendidikan, usia perkawinan pertama dan kematian bayi terhadap fertilitas di Kabupaten Aceh Timur. Penelitian menggunakan data primer dengan responden sebanyak 97 orang dari tiga kecamatan. Kemudian analisis data yang digunakan adalah regresi linier berganda. Berdasarkan hasil diketahui bahwa pendidikan dan usia perkawinan pertama berpengaruh negatif terhadap fertilitas dan kematian bayi berpengaruh positif terhadap fertilitas. Hasil uji t menyatakan bahwa pendidikan serta kematian bayi berpengaruh tidak signifikan terhadap fertilitas; sementara usia perkawinan pertama berpengaruh signifikan terhadap fertilitas. Hasil uji F menyatakan bahwa secara simultan pendidikan, usia perkawinan pertama dan kematian bayi berpengaruh signifikan terhadap fertilitas di Kabupaten Aceh Timur.
\end{abstract}

Kata kunci: Fertilitas, tingkat pendidikan, usia perkawinan pertama, kematian bayi.

\section{PENDAHULUAN}

Penduduk merupakan faktor yang strategis dalam pembangunan. Terdapat beberapa alasan yang melandasi pemikiran bahwa kependudukan merupakan faktor yang sangat strategis dalam kerangka pembangunan nasional. Pertama, kependudukan, atau dalam hal ini adalah penduduk, merupakan pusat dari seluruh kebijaksanaan dan program pembangunan yang dilakukan. Dalam Rencana Pembangunan Jangka Menengah dan Panjang dengan jelas dikemukakan bahwa penduduk adalah subyek dan obyek pembangunan. Sebagai subyek pembangunan maka penduduk harus dibina dan dikembangkan sehingga mampu menjadi penggerak pembangunan. Sebaliknya, pembangunan juga harus dapat dinikmati oleh penduduk yang bersangkutan.

Kedua, keadaan dan kondisi kependudukan yang ada sangat mempengaruhi dinamika pembangunan yang dilakukan oleh pemerintah. Jumlah penduduk yang besar jika diikuti dengan kualitas penduduk yang memadai akan merupakan pendorong bagi pertumbuhan ekonomi. Sebaliknya, jumlah penduduk yang besar jika diikuti dengan tingkat kualitas yang rendah, menjadikan penduduk tersebut sebagai beban bagi pembangunan.

Ketiga, dampak perubahan dinamika kependudukan baru akan terasa dalam jangka yang panjang. Karena dampaknya baru terasa dalam jangka waktu yang panjang, sering kali peranan penting dari penduduk di dalam pembangunan terabaikan. Dengan demikian, jika tidak diindahkannya dimensi kependudukan dalam rangka pembangunan nasional, sama artinya dengan akan "menyengsarakan" generasi berikutnya.

Aceh Timur merupakan salah satu Kabupaten yang berada di sisi timur Provinsi Aceh, Indonesia. Kabupaten Aceh Timur terdiri dari 24 kecamatan, 513 desa serta 54 
pemukiman. Jumlah penduduk di Kabupaten Aceh Timur selalu mengalami peningkatan di setiap tahunnya. Pada tahun 2012 jumlah penduduk meningkat dari tahun sebelumnya sebesar 2,20\%; kemudian pada tahun 2013 meningkat menjadi $2,05 \%$; selanjutnya pada tahun 2014 jumlah penduduk meningkat sebesar 2,25\%; serta pada tahun 2015 jumlah penduduk meningkat menjadi sebesar 2,03\%.

Pertumbuhan penduduk disebabkan oleh fertilitas, mortalitas dan migrasi. Fertilitas merupakan kemampuan menghasilkan keturunan yang dikaitkan dengan kesuburan wanita. Usia antara 15-49 tahun merupakan usia subur bagi seorang wanita, karena pada usia tersebut kemungkinan wanita melahirkan anak cukup besar. Ada beberapa faktor yang mempengaruhi fertilitas (Wibowo, 2008), yaitu: (1) faktor sosial ekonomi yang meliputi pendapatan, pekerjaan, pendidikan; (2) faktor biologis yang meliputi usia perkawinan pertama, lamanya kawin dan waktu senggang; (3) faktor demografi yang meliputi struktur umur, status perkawinan dan kematian dalam setahun; serta, (4) alat kontrasepsi yang digunakan.

Tingkat pendidikan sangat berkaitan erat dengan sikap dan pandangan hidup suatu masyarakat. Pendidikan bisa melatarbelakangi seseorang untuk mendapat pengetahuan yang lebih luas. Tinggi rendahnya pendidikan akan mempengaruhi umur kawinan pertama, yang akan mempengaruh fertilitas. Wanita yang tingkat pendidikannya lebih tinggi umumnya usia perkawinan pertama juga tinggi dan pada akhirnya akan mempengaruhi jumlah anak yang dilahirkan lebih sedikit. Tingkat pendidikan penduduk kabupaten Aceh Timur pada tahun 2016 yang belum sekolah sebanyak 109.860 jiwa atau $26,10 \%$ dari jumlah penduduk; Sekolah Dasar (SD) sebanyak 176.060 jiwa atau 41,82\%; Sekolah Menengah Pertama (SMP) sebanyak 67.089 jiwa atau 15,94\%; Sekolah Menengah Atas (SMA) sebanyak 55.521 jiwa atau 13,19\%; Diploma sebanyak 6.160 jiwa atau 1,46\%; dan, Sarjana sebanyak 6.308 jiwa atau 1,49\%.

Kemudian faktor yang mempengaruhi fertilitas yaitu struktur umur. Umur wanita sangat berkaitan erat dengan fertilitas. Wanita yang menikah pada saat usia muda, tingkat pendidikan lebih rendah dan keadaan sosial ekonominya lebih rendah. Sebaliknya wanita menikah setelah memiliki pendidikan dan keadaan sosial ekonomi maka jumlah anaknya lebih sedikit, karena usia pernikahan lebih tua. Hal tersebut menyebabkan tingkat pendidikan dan keadaan sosial ekonominya juga lebih baik (Israwati, 2009).

Kematian bayi merupakan salah satu komponen yang mempengaruhi jumlah penduduk, selain fertilitas dan migrasi. Angka kematian digunakan sebagai indikator yang berhubungan dengan kesehatan dan pembangunan manusia. Angka kematian bayi merupakan jumlah anak yang meninggal pada saat umur kurang dari 1 tahun. Bayi yang usianya kurang dari 1 tahun biasanya memiliki resiko kematian yang lebih besar dibandingkan pada kelompok balita. Hal ini dikarenakan bayi umur kurang dari 1 tahun lebih rentan bisa terkena penyakit. Jumlah kematian bayi di Kabupaten Aceh Timur tahun 2014 sebanyak 135 jiwa, dan pada tahun 2015 menurun menjadi 87 orang.

Berdasarkan latar belakang penelitian tersebut, maka yang menjadi tujuan dalam penelitian ini adalah untuk mengetahui: (1) pengaruh tingkat pendidikan, usia perkawinan pertama dan kematian bayi secara parsial terhadap fertilitas di Kabupaten Aceh Timur; serta, (2) pengaruh tingkat pendidikan, usia perkawinan pertama dan kematian bayi secara simultan terhadap fertilitas pada Kabupaten Aceh Timur.

\section{Tingkat Pendidikan}

Todaro (2006) menyatakan bahwa tingkat pendidikan terdiri dari dua bagian, dimana bobot dua pertiganya untuk kemampuan baca tulis, dan sepertiganya adalah untuk masa bersekolah. Hal ini dapat dirumuskan:

Indeks pendidikan $=2 / 3$ (Indeks Kemampuan baca tulis orang dewasa) + 1/3 (indek masa bersekolah bruto).

Todaro (2006) juga menyatakan bahwa masa bersekolah bruto dapat melebihi 100 persen. Hal ini dikarenakan siswa yang tua dapat kembali bersekolah. Indeks angka 
melek huruf ini dibatasi hingga seratus persen, dengan rumus:

$$
\begin{gathered}
\text { Indeks kemampuan baca tulis orang dewasa } \\
=\frac{(\text { Kemampuan baca tulis }(\%)-0)}{(100-0)}
\end{gathered}
$$

Menurut Andrew E. Sikula dalam Mangkunegara (2009), tingkat pendidikan adalah suatu proses jangka panjang yang menggunakan prosedur sistematis dan terorganisir, yang mana tenaga kerja manajerial mempelajari pengetahuan konseptual dan teoritis untuk tujuan-tujuan umum. Menurut Sumarsono (2009), pendidikan adalah suatu proses yang bertujuan untuk menambah keterampilan, pengetahuan dan meningkatkan kemandirian maupun kepribadian seorang individu. Menurut Israwati (2009), tingkat pendidikan erat kaitannya dengan perubahan sikap, perilaku, pandangan, dan status sosial ekonomi suatu masyarakat.

Dengan perkembangan waktu pendidikan, terutama pendidikan wanita semakin baik dibanding dengan waktu sebelum kemerdekaan. Wanita yang memperoleh kesempatan pendidikan tidak hanya di daerah perkotaan saja, namun juga dialami wanita di daerah pedesaan. Tinggi rendahnya tingkat pendidikan akan mempengaruhi umur perkawinan pertama, yang pada akhirnya akan mempengaruhi fertilitas. Wanita yang tingkat pendidikannya lebih tinggi umumnya umur perkawinan pertama juga tinggi, dan pada akhirnya akan mempengaruhi jumlah anak yang dilahirkan yang akan lebih sedikit.

Berdasarkan Undang-Undang Sistem Pendidikan Nasional (UU SISDIKNAS) (2003), tingkat pendidikan adalah tahapan pendidikan yang ditetapkan berdasarkan tingkat perkembangan peserta didik, tujuan yang akan dicapai dan kemampuan yang dikembangkan. Menurut UU SISDIKNAS (2003), indikator tingkat pendidikan terdiri dari jenjang pendidikan dan kesesuaian jurusan. Jenjang pendidikan adalah tahapan pendidikan yang ditetapkan berdasarkan tingkat perkembangan peserta didik, tujuan yang akan dicapai, dan kemampuan yang dikembangkan, terdiri dari:

1. Pendidikan dasar: jenjang pendidikan awal selama 9 (sembilan) tahun pertama masa sekolah anak-anak yang melandasi jenjang pendidikan menengah.

2. Pendidikan menengah: jenjang pendidikan lanjutan pendidikan dasar.

3. Pendidikan tinggi: jenjang pendidikan setelah pendidikan menengah yang mencakup program sarjana, magister, doktor, dan spesialis yang diselenggarakan oleh perguruan tinggi atau Universitas.

Ananta (2009) menyatakan bahwa pendidikan yang tinggi sering kali mendorong kesadaran untuk tidak memiliki anak banyak. Dengan pendidikan yang tinggi, orang cenderung memilih untuk mempunyai anak dalam jumlah kecil tapi bermutu dibandingkan dengan memiliki banyak anak tapi tidak bermutu. Seseorang yang memiliki status pendidikan yang tinggi pada umumnya akan menunda pernikahannya karena lebih berorientasi pada aspek pendidikannya dan pekerjaan yang layak. Selain itu, pendidikan juga berpengaruh atas pengetahuan tentang rentang usia yang tepat untuk merencanakan kehamilan. Sebaliknya, jika seseorang kurang memiliki tingkat pendidikan tinggi, besar kemungkinan ia akan cenderung untuk memilih menikah di usia dini. Hal ini akan memperbesar peluang banyaknya bayi yang lahir dalam satu keluarga serta menjadi alasan mengapa jumlah remaja yang melahirkan semakin banyak (Notoatmojo, 2008).

\section{Usia Perkawinan Pertama}

Rata-rata umur penduduk saat menikah pertama kali serta lamanya seseorang dalam status perkawinan akan mempengaruhi tinggi rendahnya fertilitas. Usia kawin dini menjadi perhatian terkait penentuan kebijakan serta perencana program karena beresiko tinggi terhadap kegagalan perkawinan, kehamilan usia muda yang beresiko kematian, serta resiko tidak siap mental untuk membina perkawinan dan menjadi orang tua yang bertanggung jawab (Statistik Indonesia, 2014). Daljoeni (2008) mengemukakan bahwa dengan usia kawin 17 tahun, seorang gadis dalam hidup perkawinan dapat melahirkan delapan orang anak. Apabila usia kawin ditingkatkan ke usia 22 tahun, jumlah anak 
menjadi tujuh orang anak; dan apabila usia kawin ditingkatkan ke usia 27 tahun, maka jumlah anak menjadi empat orang.

Menurut Davis \& Blake dalam Saifuddin (2010), umur memulai hubungan kelamin merupakan salah satu variabel yang memungkinkan diadakannya senggama dan menguntungkan fertilitas. Perkawinan yang diadakan pada umur muda setidak-tidaknya menjamin orang-orang muda itu mempunyai keturunan sebelum mereka menutup usia. Sementara Chilman dalam Saifuddin (2010) menunjukkan bahwa hal-hal seperti tingkat usia yang terlalu muda untuk kawin, maka anak pertama lahir terlalu cepat, dan keluarga besar memiliki hubungan dengan kemiskinan. Unsur-unsur ini juga mempunyai kaitan dengan faktor-faktor lain, seperti faktor sosial dan faktor lingkungan.

\section{Kematian Bayi/Mortalitas Bayi}

Menurut Notoatmodjo (2008), tingkat kesehatan suatu bangsa dapat dilihat dari angka kematian (mortalitas). Angka kematian bayi merupakan salah satu indikator yang sering digunakan untuk mengukur derajat kesehatan suatu bangsa, dan juga sebagai indikator kualitas sumber daya manusia dari aspek kesehatan. Indikator lainnya adalah angka kematian balita, angka kematian ibu karena melahirkan, angka kematian kasar, dan angka harapan hidup. Menurut Wandira dan Rahmah (2012), kematian bayi adalah seseorang yang meninggal pada saat umur kurang dari 1 tahun. Bayi yang usianya kurang dari satu tahun umumnya memiliki resiko kematian lebih besar dibandingkan pada kelompok balita. Menurut Saifuddin (2010), mortalitas atau kematian bayi merupakan salah satu faktor yang dapat mempengaruhi tingkat perubahan penduduk. Komponen ini bukan saja berpengaruh bagi pemerintah secara keseluruhan, melainkan perlu juga bagi pihak swasta, terutama yang berkecimpung dalam bidang ekonomi dan kesehatan.

Wandira dan Rahmah (2012) menyatakan bahwa banyak sekali faktor yang dikaitkan dengan kematian bayi. Secara garis besar dari segi penyebabnya, kematian bayi dibedakan atas dua jenis, yaitu kematian endogen dan kematian eksogen. Kematian bayi endogen adalah kematian bayi disebabkan oleh faktorfaktor anak yang dibawa sejak lahir, diwariskan oleh orang tuanya pada saat konsepsi, atau didapat dari ibunya sejak kehamilan. Kematian bayi eksogen adalah kematian bayi disebabkan oleh faktor-faktor yang berkaitan dengan pengaruh lingkungan.

\section{Fertilitas}

Menurut James T. Fawcett dalam Saifuddin (2010), fertilitas adalah jumlah kelahiran yang terjadi dalam penduduk tertentu dan dalam waktu tertentu. Dalam studi fertilitas, jumlah diberikan batas-batas yang teliti, misalnya tingkat kelahiran kasar, tingkat kelahiran menurut umur tertentu, tingkat fertilitas umum, dan tingkat reproduksi kotor. Fertilitas dalam pengertian demografi adalah kemampuan seorang wanita secara riel untuk melahirkan.Kemampuan seorang wanita untuk melahirkan berbeda antara wanita yang satu dengan lainnya, begitu pula antara satu penduduk dengan penduduk yang lainnya (BKKBN, 2007).

Mantra (2006) menyatakan bahwa fertilitas adalah sama dengan kelahiran hidup (live birth), yaitu terlepasnya bayi dari Rahim seorang perempuan dengan ada tanda-tanda kehidupan, misalnya berteriak, bernafas, jantung berdenyut, dan lain sebagainya. Selanjutnya Rahma (2008) berpendapat bahwa kelahiran dapat diartikan sebagai hasil reproduksi yang nyata dari seorang wanita atau kelompok wanita. Fertilitas merupakan taraf kelahiran penduduk yang sesungguhnya berdasarkan jumlah kelahiran yang terjadi. Pengertian ini digunakan untuk menunjukkan pertambahan jumlah penduduk. Fertilitas disebut juga dengan natalitas.

Menurut Hatmadji (2008), fertilitas adalah hasil reproduksi yang nyata dari seorang wanita atau sekelompok wanita. Dengan kata lain, fertilitas ini menyangkut banyaknya bayi yang lahir hidup. Fertitlitas mencakup peranan kelahiran pada perubahan penduduk. Seorang perempuan yang secara biologis subur tidak selalu melahirkan anakanak yang banyak, misalnya dia mengatur 
fertilitas dengan menggunakan alat-alat kontrasepsi. Kemampuan biologis seseorang perempuan untuk melahirkan sangat sulit untuk diukur. Jadi pengukuran fertilitas lebih kompleks dibandingkan dengan pengukuran mortalitias, karena seorang perempuan hanya meninggal sekali tetapi ia dapat melahirkan lebih dari seorang bayi.

\section{Faktor yang Mempengaruhi Fertilitas}

Faktor-faktor yang mempengaruhi tigkat fertilitas dapat dibedakan menjadi faktor yang langsung dapat mempengaruhi dan yang tidak langsung mempengaruhi. Menurut Mantra (2006), faktor tidak langsung yang berpengaruh adalah unsur demografi, yaitu struktur umur, status perkawinan dan proporsi perkawinan. Faktor yang kedua adalah unsur non demografi, antara lain keadaan penduduk, tingkat pendapatan keluarga, tingkat pendidikan, perbaikan status wanita, urbanisasi, penggunaan alat kontrasepsi, serta tingkat pengetahuan KB. Tingginya angka kelahiran erat kaitannya dengan usia kawin pertama dengan pembentukan keluarga kecil yang berkualitas. Menurut Davis dan Blake (dalam Saifuddin, 2010), ada sebelas variabel antara yang berpengaruh langsung terhadap fertilitas, yang dikategorikan dalam tiga kelompok besar, yaitu intercourse variables, conception variables, dan gestation variables.

Intercourse variables adalah faktorfaktor yang mempengaruhi kemungkinan untuk hubungan kelamin. Kelompok ini dibedakan menjadi dua, yaitu:

1. Faktor-faktor yang mempengaruhi pembentukan dan perceraian hubungan kelamin (sexual union) dalam masa reproduksi:

a. Umur memulai hubungan kelamin.

b. Selibat permanen; yaitu proporsi wanita yang tak pernah mengadakan hubungan kelamin

c. Lamanya periode reproduksi yang hilang sesudah atau diantara masa hubungan kelamin, dimana:

- Bila hidup sebagai suami istri itu berakhir karena perceraian, berpisah atau salah seorang melarikan diri.

- Bila hidup sebagai suami istri itu berakhir karena suami meninggal.
2. Faktor-faktor yang mempengaruhi tingkat kemungkinan untuk hubungan kelamin, yaitu:

a. Abstinensi sukarela.

b. Abstinensi terpaksa (impotensi, sakit, berpisah sementara yang tak terhindari)

c. Frekuensi hubungan seks (tidak termasuk masa abstiensi).

Conception variables adalah faktorfaktor yang mempengaruhi kemungkinan untuk hubungan kelamin, yaitu:

1. Kesuburan atau kemandulan yang dipengaruhi oleh sebab-sebab di luar kemauan.

2. Menggunakan atau tak menggunakan metode-metode kontrasepsi, dimana:

a. Menggunakan cara-cara mekanik dan bahan-bahan kimia.

b. Menggunakan cara lain

3. Kesuburan atau kemandulan yang dipengaruhi oleh sebab-sebab yang disengaja sterilisasi, subinsisi, obat-obatan dan sebagainya).

Terakhir adalah gestation variables, yaitu faktor-faktor yang mempengaruhi kehamilan dan kelahiran dengan selamat.

Menurut Davis dan Blake dalam Saifuddin (2010), umur memulai hubungan kelamin merupakan salah satu variabel yang memungkinkan diadakannya senggama dan menguntungkan fertilitas. Perkawinan yang diadakan pada umur muda setidak-tidaknya menjamin orang-orang muda itu mempunyai keturunan sebelum mereka menutup usia. Pengendalian pertumbuhan penduduk juga merupakan faktor penting dalam peningkatan keluarga kecil yang berkualitas. Oleh karena itu, untuk menekan jumlah kelahiran dapat dilakukan dengan cara memperbaiki tingkat pendidikan dan meningkatkan usia kawin pertama pada masyarakat. Menurut Freedman dalam Singarimbun (2004), variabel antara yang mempengaruhi langsung terhadap fertilitas pada dasarnya juga dipengaruhi oleh norma-norma yang berlaku di suatu masyarakat. Pada akhirnya, perilaku fertilitas seseorang dipengaruhi norma-norma yang ada yaitu norma tentang besarnya keluarga dan norma tentang variabel antara itu sendiri. 
Menurut Davis dan Blake dalam Oktavia (2014), terdapat beberapa faktor yang mempengaruhi fertilitas, yaitu:

1. Pendekatan sosial. Salah satu pendekatan ilmu sosial tentang faktor-faktor yang mempengaruhi fertilitas adalah pendekatan sosial. Ada tiga tahap penting dalam proses kelahiran, yatu tahap hubungan kelamin, tahap konsepsi dan tahap kehamilan. Ketiga tahap ini sangat dipengaruhi oleh kondisi sosial, ekonomi dan budaya dimana perempuan dan masyarakat tinggal.

2. Pendekatan ekonomi. Mempunyai anak dapat dilihat dari dua segi ekonomi, yaitu segi kegunaannya (utility) dan biaya (cost) yang harus dikeluarkan untuk membesarkan dan merawat anak. Kegunaannya (utility) anak adalah dalam memberikan kepuasan kepada orang tua, dapat memberi transfer ekonomi misalnya memberikan kiriman uang kepada orang tua pada saat dibutuhkan.

3. Tingkat pendidikan. Pendidikan adalah suatu proses yang bertujuan untuk menambah keterampilan, pengetahuan dan meningkatkan kemandirian maupun kepribadian seorang individu.

4. Struktur umur. Umur wanita sangat besar pengaruhnya terhadap fertilitas, dimana hal ini berkaitan dengan umur perkawinan pertama dan umur kumpul pertama. Wanita yang berumur lebih tua biasanya umur kawinnya lebih muda, dengan demikian tingkat pendidikannya juga lebih rendah, dan keadaan sosial ekonominya lebih rendah.

5. Kematian bayi. Mortalitas bayi adalah salah satu komponen demografi selain fertilitas dan migrasi yang mempengaruhi jumlah, struktur dan komposisi penduduk. Angka kematian juga digunakan sebagai indikator yang terkait dengan derajat kesehatan dan pembangunan manusia.

\section{Hubungan Tingkat Pendidikan dan Fertilitas}

Menurut Israwati (2009), wanita yang memperoleh kesempatan pendidikan tidak hanya di daerah perkotaan saja, namun juga dialami wanita di daerah pedesaan. Tinggi rendahnya tingkat pendidikan akan dapat mempengaruhi umur perkawinan pertama, yang pada akhirnya akan mempengaruhi fertilitas. Selajutnya Hawthorn (dalam Saleh, 2008) menyatakan bahwa dalam masyarakat, kesadaran akan pembatasan kelahiran memang tergantung pada latar belakang daerah kota atau tempat tinggal, pendidikan dan penghasilan. Menurut Todaro (2006), semakin tinggi tingkat pendidikan istri atau wanita cenderung untuk merencanakan jumlah anak yang semakin sedikit. Keadaan ini menunjukkan bahwa wanita yang telah mendapatkan pendidikan lebih baik cenderung memperbaiki kualitas anak dengan cara memperkecil jumlah anak, sehingga akan mempermudah dalam perawatannya, melakukan pembimbingan serta memberikan pendidikan yang lebih layak.

\section{Hubungan Usia Perkawinan Pertama dan Fertilitas}

Israwati (2009) menyatakan bahwa umur wanita sangat besar pengaruhnya terhadap fertilitas, dimana hal ini berkaitan dengan umur perkawinan pertama. Wanita yang berumur lebih tua biasanya umur kawinnya lebih muda, dengan demikian tingkat pendidikannya juga lebih rendah dan keadaan sosial ekonomi lebih rendah. Sebaliknya, wanita-wanita muda jumlah anaknya lebih sedikit, karena umur kawin pertamanya lebih tinggi, maka tingkat pendidikannya juga lebih tinggi dan keadaan sosial ekonominya juga lebih baik. Dalam BPS Indonesia (2014), dinyatakan bahwa umur pada saat perkawinan pertama dapat mempengaruhi kesehatan reproduksi wanita. Seorang wanita cenderung akan mempunyai resiko yang semakin lebih besar ketika melahirkan, bahkan tidak jarang menimbulkan kematian pada ibu atau bayi yang dilahirkan bila umur perkawinan pertama semakin muda.

\section{Hubungan Kematian Bayi dan Fertilitas}

Menurut Lembaga Demografi FE UI (dalam Oktavia, 2014), kematian/mortalitas bayi (infant mortality) yang dihubungkan 
dengan reproduksi, jika kematian bayi perempuan berkurang berarti mereka yang akan memasuki usia reproduksi semakin bertambah, akibatnya ada kecenderungan angka kelahiran (fertilitas) bertambah. Menurut Munir (2009), fertilitas yang tinggi memiliki hubungan dengan mortalitas bayi yang menurun dan berpengaruh terhadap perkembangan pertumbuhan penduduk di suatu daerah.

\section{Penelitian sebelumnya}

Oktavia (2014) melakukan penelitian mengenai pengaruh tingkat pendidikan, struktur umur dan kematian bayi terhadap fertilitas di Kota Pekan Baru. Penelitian ini menggunakan data primer dengan jumlah responden sebanyak 100 orang. Hasil penelitian menunjukkan bahwa tingkat pendidikan berpengaruh terhadap jumlah anak yang dilahirkan, yang diketahui dari hasil penelitian sebanyak 7 orang dengan tamat SD, memiliki anak sampai dengan 4 orang; responden dengan tingkat pendidikan SMP memiliki anak 2-3 orang; tingkat pendidikan SMA sebanyak 48 orang memiliki anak 2 orang; dan, perguruan tinggi sebanyak 10 orang memiliki anak 1 orang saja.

Hasil penelitian Oktavia (2004) juga menunjukkan pengaruh struktur umur terhadap fertilitas dapat diketahui 12 orang responden yang menikah pada usia $<20$ tahun; dan, 7 orang responden mempunyai anak 2 orang. Sementara itu, responden yang berumur 20-24 tahun rata-rata memiliki 3 orang anak; yang menikah pada usia 25-29 paling banyak mempunyai anak 1 orang; serta, yang menikah pada usia 30-34 tahun dan > 35 tahun memiliki jumlah anak yang dilahirkan 1-2 orang saja, tidak lebih. Dengan demikian, pada usia 20-24 tahun, jumlah anak yang dilahirkan responden masih banyak. Hal ini karena berdasarkan kesehatan reproduksi, usia ini merupakan usia ideal bagi seorang wanita menikah, sehingga kecil kemungkinan wanita akan beresiko saat hamil maupun melahirkan.

Berkaitan dengan pengaruh kematian bayi terhadap fertilitas, hasil penelitian Oktavia (2004), menemukan bahwa dari 10 orang responden yang mempunyai bayi yang meninggal, 9 orang diantaranya mempunyai 1 orang bayi yang meninggal; dari 9 orang responden ini, ada yang telah melahirkan anak 2 orang, 3 orang dan $>4$ orang. Kemudian ada 1 orang responden yang mempunyai anak yang meninggal sebanyak 2 orang dengan anak yang dilahirkan sebanyak $>4$ orang.

Kartika dan Wenagama (2016) melakukan penelitian mengenai pengaruh faktor sosial ekonomi terhadap usia kawin pertama wanita di Kecamatan Bangli. Penelitian ini dilakukan untuk mengetahui pengaruh langsung faktor sosial ekonomi terhadap usia kawin pertama wanita. Data yang digunakan adalah data primer yang bersumber dari kuesioner dengan jumlah responden sebanyak 99 orang. Teknik analisis yang digunakan adalah regresi linier berganda. Hasil yang diperoleh menunjukkan bahwa pendidikan, status bekerja, dan pendapatan secara simultan berpengaruh signifikan terhadap usia kawin pertama wanita di Kecamatan Bangli. Secara parsial, pendidikan, status bekerja, dan pendapatan berpengaruh positif dan signifikan terhadap usia kawin pertama di Kecamatan Bangli.

\section{Hipotesis}

Berdasarkan tinjauan teoritis dan empiris, dua hipotesis diajukan dalam penelitian ini. Hipotesis pertama menyatakan bahwa tingkat pendidikan, usia perkawinan pertama dan kematian bayi secara parsial berpengaruh negatif dan signifikan terhadap fertilitas di Kabupaten Aceh Timur. Hipotesis kedua menyatakan bahwa tingkat pendidikan, usia perkawinan pertama dan kematian bayi secara simultan berpengaruh negatif dan signifikan terhadap fertilitas di Kabupaten Aceh Timur.

\section{METODE PENELITIAN}

\section{Jenis dan Sumber Data}

Jenis data yang digunakan dalam penelitian ini adalah data primer, yaitu data yang diperoleh dengan cara melakukan penelitian langsung melalui wawancara, observasi dan kuesioner. 


\section{Populasi dan Sampel}

Populasi penelitian ini adalah wanita yang berumur 50 tahun atau lebih di Kabupaten Aceh Timur, yaitu sebanyak 3.510 jiwa (Dinas Kependudukan dan Catatan Sipil, 2017). Populasi tersebut tersebar di tiga kecamatan, yaitu Kecamatan Peureulak yang mewakili daerah perkotaan, Kecamatan Darul Falah mewakili wilayah pinggiran, dan Kecamatan Peunaron yang mewakili daerah pedalaman.

Tekhnik pengambilan sampel menggunakan Cluster sampling, yaitu tehnik sampling daerah untuk menentukan sampel bila obyek yang akan diteliti atau sumber data sangat luas. Tehnik ini menggunakan dua tahap, yaitu tahap penentuan sampel daerah dan tahap penentuan orang-orang yang menjadi sampel. Penentuan sampel daerah menggunakan teknik purposive sampling, yaitu dengan pertimbangan daerah yang memiliki penduduk perkotaan, pinggiran kota dan pedalaman. Jadi terdapat tiga daerah yang menjadi sampel, yaitu Peureulak dengan jumlah penduduk sebanyak 2.413 jiwa, Darul Falah sebayak 315 jiwa, dan Peunaron sebanyak 782 jiwa (Dinas Kependudukan dan Pencatatan Sipil Kabupaten Aceh Timur, 2017). Selanjutnya, dari jumlah tersebut diambil sampel dengan rumus Slovin yang dikemukakan Sinulingga (2013:217), yaitu:

$$
n=\frac{N}{1+N e^{2}}
$$

dimana $N$ adalah ukuran populasi, $e$ adalah tingkat error (10\%), dan $n$ adalah ukuran sampel. Hasil perhitungan menggunakan rumus tersebut adalah:

$$
\begin{aligned}
n & =\frac{3.510}{1+\left[3.510 \times(0,1)^{2}\right]} \\
& =97,22 \approx 97 \text { orang. }
\end{aligned}
$$

Dari hasil perhitungan tersebut maka diketahui besar sampel yang diperlukan minimal berjumlah 97 orang.

\section{Metode Pengumpulan Data}

Data yang dibutuhkan pada penelitian ini diperoleh dengan menggunakan dua cara pengumpulan data, yaitu studi kepustakaan dan penelitian lapangan.

Studi Kepustakaan (Library Research) merupakan cara untuk memperoleh data yang dilakukan dengan membaca buku-buku dari perpustakaan serta bacaan lainnya yang berhubungan dengan isi tulisan ini, dimana data yang diperoleh sekunder sebagai data pendukung pada penelitian ini.

Penelitian Lapangan meliputi observasi, wawancara, kuesioner. Observasi yaitu metode pengumpulan data melalui pengamatan kegiatan sehari-hari yang dilakukan oleh responden; sementara wawancara yaitu metode pengumpulan data dengan melakukan wawancara pada responden untuk mendapatkan informasi yang diinginkan mengenai keadaan yang sedang dialami responden. Kuesioner yaitu pengumpulan data menggunakan sejumlah pertanyaan tertulis untuk memperoleh informasi dari responden dalam arti laporan tentang pribadinya atau hal-hal yang di ketahui. Kuesioner disebarkan kepada 97 orang responden penelitian.

\section{Metode Analisis Data}

Proses analisis data menggunakan persamaan regresi linier berganda yang dikemukakan oleh Situmorang dan Lufti (2014), yaitu:

$$
Y=\alpha+\beta_{1} X_{1}+\beta_{2} X_{2}+\beta_{3} X_{3}+e
$$

dimana $Y$ adalah fertilitas; $\alpha$ adalah konstanta; $\beta_{1}, \beta_{2}$ dan $\beta_{3}$ adalah koefisien regresi untuk masing-masing variabel bebas; $X_{1}$ adalah tingkat pendidikan, $X_{2}$ adalah usia perkawinan pertama; $X_{3}$ adalah kematian bayi; dan, $e$ adalah error term.

Setelah uji persamaan regresi linier berganda dilakukan, dilanjutkan dengan pengujian hipotesis menggunakan uji t, uji $\mathrm{F}$, dan koefisien determinasi $\left(\mathrm{R}^{2}\right)$.

\section{HASIL ANALISIS}

Pengaruh tingkat pendidikan, struktur umur dan kematian bayi terhadap fertilitas di Kabupaten Aceh Timur dianalisis menggunakan persamaan regresi linier berganda dan diolah dengan program statistik SPSS versi 20,0. Hasil koefisien dilihat pada Tabel 1. 
Tabel 1. Deskripsi Penelitian

\begin{tabular}{lrrr}
\hline \multicolumn{1}{c}{ Variabel } & B & $\mathrm{t}$ & Sig. t \\
\hline Konstanta & 1,922 & 7,215 &, 000 \\
Pendidikan Istri &,- 013 &,- 273 &, 785 \\
usia perkawinan pertama (istri) &,- 033 & $-6,348$ &, 000 \\
Jumlah Kematian Bayi (<1thn) &, 032 &, 356 &, 723 \\
\hline R Square & $=$ & 0,340 & \\
F & 15,994 & & \\
Sig. F &, $000^{\mathrm{b}}$ & & \\
\hline
\end{tabular}

Sumber: Data primer (diolah), tahun 2018

Berdasarkan hasil analisis regresi dalam Tabel 1, maka dapat diformulasikan model penelitian ini:

$$
\mathrm{Y}=1,922-0,013 \mathrm{X}_{1}-0,033 \mathrm{X}_{2}+0,032 \mathrm{X}_{3} \text {. }
$$

Dari persamaan regresi linier berganda tersebut, maka dapat diinterpretasikan sebagai berikut:

- Nilai konstanta memiliki nilai yang positif sebesar 1,922. Hasil ini berarti bahwa jika nilai variabel pendidikan, umur dan kematian bayi dianggap tetap maka fertilitas (jumlah bayi kurang 1 tahun) adalah sebesar 1,922.

- Koefisien regresi pendidikan bernilai negatif sebesar -0,013 menunjukkan bahwa terdapat pengaruh yang negatif antara variabel bebas pendidikan dengan variabel terikat fertilitas, yaitu apabila pendidikan meningkat satu tingkat maka akan menurunkan fertilitas sebesar 0,013.

- Koefisien regresi pendidikan bernilai negatif sebesar -0,033 menunjukkan bahwa terdapat pengaruh yang negatif antara variabel bebas umur dengan variabel terikat fertilitas, yaitu apabila umur meningkat satu tahun maka akan menurunkan fertilitas sebesar 0,033.

- Koefisien regresi kematian bayi bernilai positif sebesar 0,032 menunjukkan bahwa terdapat pengaruh yang positif antara variabel bebas kematian bayi dengan variabel terikat fertilitas, yaitu apabila kematian bayi meningkat satu maka akan meningkatkan fertilitas sebesar 0,032 .

\section{Pembuktian Hipotesis}

Hipotesis yang diajukan di dalam penelitian ini dibuktikan dengan menggunakan uji $t$ (uji parsial) dan uji $F$ (uji simultan).

Pengujian parsial dilakukan dengan melihat nilai $t$ signifikan (Sig. $t$ ) dibandingkan dengan nilai $\alpha(0,05)$. Berdasarkan Tabel 1 , hasil uji $t$ diuraikan sebagai berikut:

- Variabel pendidikan memiliki nilai Sig. $t$ sebesar 0,785 > $\alpha(0,05)$. Dengan demikian dapat dinyatakan bahwa pendidikan berpengaruh tidak signifikan terhadap fertilitas.

- Variabel usia perkawinan pertama memiliki nilai Sig. $t$ sebesar $0,000<\alpha$ $(0,05)$. Dengan demikian dapat dinyatakan bahwa usia perkawinan pertama berpengaruh signifikan terhadap fertilitas.

- Variabel kematian bayi memiliki nilai Sig. $t$ sebesar $0,723>\alpha(0,05)$. Dengan demikian dapat dinyatakan kematian bayi berpengaruh tidak signifikan terhadap fertilitas.

Pengujian simultan dilakukan dengan melihat nilai $F$ signifikan (Sig. $F$ ) disbandingkan dengan nilai $\alpha(0,05)$. Hasil uji $F$ yang diperoleh

Pengujian dilakukan dengan melihat $\mathrm{F}$ signifikan pada tabel 1.dan nilai $\alpha 5 \%$. Berdasarkan Tabel 1 dapat diketahui bahwa nilai Sig. $F$ sebesar $0,000<0,05$. Dengan demikian dapat dinyatakan bahwa secara simultan, pendidikan, usia perkawinan pertama dan kematian bayi berpengaruh signifikan terhadap fertilitas di Kabupaten Aceh Timur. 
Hasil koefisien determinasi $\left(\mathrm{R}^{2}\right)$ pada Tabel 1 menunjukkan nilai sebesar 0,340 . Hasil ini menyatakan bahwa ketiga variabel bebas yang dianalisis dalam penelitian ini, yaitu pendidikan, usia perkawinan pertama dan kematian bayi, berkontribusi sebesar 34\% dalam menjelaskan varians yang terjadi atas fertilitas. Sementara itu, sisanya sebesar $66 \%$ dipengaruhi oleh variabel-variabel lain yang tidak masuk dalam model penelitian ini.

\section{KESIMPULAN}

Berdasarkan hasil pembahasan yang dilakukan dapat disimpulkan beberapa hal. Pertama, hasil analisis regresi menyatakan bahwa pendidikan dan usia perkaainan pertama berpengaruh secara negatif terhadap fertilitas, sementara kematian bayi memiliki pengaruh positif terhadap fertilitas di Kabupaten Aceh Timur. Kedua, hasil uji t atau uji parsial menyatakan bahwa pendidikan dan kematian bayi berpengaruh tidak signifikan terhadap fertilitas; sementara usia perkawinan pertama berpengaruh signifikan terhadap fertilitas. Ketiga, hasil uji $\mathrm{F}$ atau uji simultan menyatakan secara simultan pendidikan, usia perkawinan pertama dan kematian bayi berpengaruh signifikan terhadap fertilitas di Kabupaten Aceh Timur. Keempat, hasil koefisien determinasi $\left(\mathrm{R}^{2}\right)$ menyatakan 34\% pendidikan, umur dan kematian bayi memiliki kontribusi sebesar 34\% atas varians fertilitas, sementara sisanya dipengaruhi oleh variabelvariabel lain yang tidak masuk dalam model penelitian ini.

Berdasarkan kesimpulan itu, beberapa saran dapat disampaikan. Pertama, bagi Pemerintah Kabupaten Aceh Timur dapat meningkatkan pendidikan masyarakat di Kabupaten Aceh Timur, yang meningkatkan pengetahuan dan dapat mengurangi angka fertilitas. Kedua, Pemerintah Kabupaten Aceh Timur dapat memberikan sosialiasi bagi yang telah berusia lanjut atau 40 tahun, di sarankan untuk tidak memiliki anak karena lebih rentan terhadap kematian ibu. Terakhir, Pemerintah Kabupaten Aceh Timur dapat memberikan sosialisasi dan penyuluhan mengenai usia kawin pertama yaitu pada umur berapa sebaiknya seorang wanita menikah.

\section{DAFTAR PUSTAKA}

Ananta, A. 2009. Ekonomi Sumber Daya

Manusia. Jakarta: Lembaga Penerbit FE UI.

Badan Pusat Statistik. 2014. Jakarta.

Daljoeni. 2008. Geografi Kota dan Desa. Bandung: Alumni.

Ghozali, I. 2011. Aplikasi Analisis Multivariate dengan Program SPSS. Semarang: Badan Penerbit Universitas Diponegoro.

Hatmadji, S.H. 2008. Dasar-Dasar Demografi. Jakarta: Lembaga Penerbit FE UI.

http://acehtimurkab.bps.go.id. 2017.

Israwati. 2009. Froximate Determinant Fertilitas di Indonesia. Jakarta: BKKBN.

Kartika, N.K.D. dan Wenagama, I.W. 2016, Pengaruh Faktor Sosial Ekonomi terhadap Usia Kawin Pertama Wanita di Kecamatan Bangli. Jurnal EP Unud. Vol. 5, No. 3, hal. 363-384.

Mangkunegara, A.P. 2009. Sumber Daya Manusia. Bandung: Rosda Karya.

Mantra, I.B. 2006. Demografi Umum. Yogyakarta: Pustaka Pelajar.

Noor, J. 2014. Analisis Data Penelitian Ekonomi dan Manajemen. Jakarta: Grasindo.

Notoadmodjo, S. 2009. Pengembangan Sumber Daya Manusia. Jakarta: Rineka Cipta.

Nurlina, dkk. 2016. Pengaruh Usia Perkawinan Pertama terhadap Tingkat Fertilitas dan Mortalitas Bayi di Kota Langsa. Laporan Penelitian. Tidak dipublikasikan. Langsa: Universitas Samudra.

Oktavia, W.Y., Putro, T.S. dan Sati, L. 2014. Pengaruh Tingkat Pendidikan, Struktur Umur dan Kematian bayi terhadap Fertilitas di Kota Pekanbaru. Jurnal Fekon. Vol. 1, No, 2, Hal. $1-15$. 
Rahma, R. 2008. Kependudukan dan Lingkungan Hidup. Jakarta:Lembaga Penerbit FE UI.

Saleh. 2008. Pengantar ilmu Kependudukan. Jakarta: LP3ES.

Singarimbun, M. 2004. Penduduk dan Perubahan. Yogyakarta: Pustaka Pelajar.

Situmorang, H. dan Muslich, L. 2014. Metode Penelitian. Medan: USU Press.

Sumarsono, S. 2009. Teori dan Kebijakan Publik. Yogyakarta: Graha Ilmu.
Syaifuddin, A.F. 2010. Integrasi Sosial Golongan Miskin di Perkotaan. Kertas Kerja dalam Workshop GAPRI.

Todaro, M.P. dan Smith, S.C. 2006. Pembangunan Ekonomi. Jakarta: Erlangga.

Undang-undang Sistem Pendidikan Nasional. 2003. Jakarta.

Wibowo, H.S. 2008. Pengaruh Tingkat Pendidikan Akseptor KB terhadap Fertilitas di Kota Pekanbaru. Skripsi. Pekanbaru: Universitas Riau. 